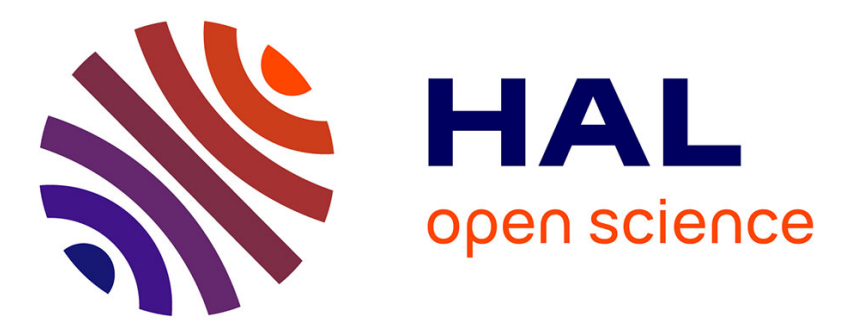

\title{
A Multi-Scale Model to explore Carbon Allocation in Plants
}

\author{
Francesco Reyes, Benoit Pallas, Christophe Pradal, Evelyne E. Costes
}

\section{To cite this version:}

Francesco Reyes, Benoit Pallas, Christophe Pradal, Evelyne E. Costes. A Multi-Scale Model to explore Carbon Allocation in Plants. 10. International Symposium on Modelling in Fruit Research and Orchard Management, Jun 2015, Montpellier, France. hal-02736071

\section{HAL Id: hal-02736071 \\ https://hal.inrae.fr/hal-02736071}

Submitted on 2 Jun 2020

HAL is a multi-disciplinary open access archive for the deposit and dissemination of scientific research documents, whether they are published or not. The documents may come from teaching and research institutions in France or abroad, or from public or private research centers
L'archive ouverte pluridisciplinaire HAL, est destinée au dépôt et à la diffusion de documents scientifiques de niveau recherche, publiés ou non, émanant des établissements d'enseignement et de recherche français ou étrangers, des laboratoires publics ou privés. 


\title{
A Multi-Scale Model to explore Carbon Allocation in Plants
}

\author{
F. Reyes ${ }^{1,2}$, B. Pallas ${ }^{3}$, C. Pradal ${ }^{4}$, E. Costes ${ }^{3}$ \\ ${ }^{1}$ Department of Sustainable Agro-ecosystems and Bioresources, Research and Innovation Centre, Fondazione E. Mach, \\ 38010 San Michele all'Adige, Italy; \\ ${ }^{2}$ Faculty of Science and Technology, Free University of Bolzano-Bozen, 39100 Bolzano, Italy; \\ ${ }^{3}$ INRA, UMR 1334 AGAP, CIRAD-INRA-Montpellier SupAgro, 34398 Montpellier Cedex 5, France; \\ ${ }^{4}$ CIRAD, INRIA project-team Virtual Plant, 34095 Montpellier Cedex 5, France.
}

Understanding and simulating carbon allocation in plants is necessary to distribute carbohydrates among growing and competing organs and to predict plant growth and structure development in relation to climatic conditions. In this context several carbon allocation models have been developed but no clear consensus exists on (i) the most appropriate topological scale (organ, metamer, compartment...) to represent this process on complex plant structures, (ii) the importance of distances between organs in carbon transport, (iii) the priorities in carbon allocation among plant parts, that can depend on growth stages. Multi-scale tree graph (MTG) is a formalism allowing the representation of geometry and topology of a tree structure at different scales. In this study, several models were implemented to compute carbon allocation at user-defined spatial scales by using the MTG formalism. This allows multiple scales (e.g. metamer, growing unit, branch) to be combined during the computation of carbon allocation (e.g. allocation first within leafy shoots at metamer scale and then between growing units). The model describes carbon transport, taking into account the distances between sources and sinks, the strength of the sinks and the available carbohydrates, following the equations of the SIMWAL and QualiTree models. Simulations on simplified branching structures, represented at different scales, showed how the scales chosen to represent the system influence the results of predicted carbon allocation. This modelling approach will be first applied to apple tree to analyze the impact of the scale of representation (branch, growth unit, metamer, and inflorescence) on the predicted fruit growth variability which, in turn, will be compared with field observations. The present work is available through the OpenAlea platform and provides existing Functional Structural Plant Models with a new generic model to simulate carbon allocation in plants depending on user-defined biological hypotheses, such as the choice of the scale of representation or the effect of distance.

Keywords: Carbon Allocation, Plant architecture, Functional Structural Plant Model, Sink Strength 